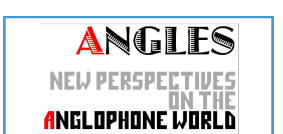

ANELOPHONE WORLI

\section{Angles}

New Perspectives on the Anglophone World

1 | 2015

Brevity is the soul of wit

\title{
Photographing the Miner's Strike at Lea Hall Colliery, 1984-1987: Interview with photographer Nigel Dickinson
}

\section{Mathilde Bertrand}

\section{(2) OpenEdition}

Journals

Electronic version

URL: https://journals.openedition.org/angles/2162

DOI: 10.4000/angles.2162

ISSN: 2274-2042

Publisher

Société des Anglicistes de l'Enseignement Supérieur

\section{Electronic reference}

Mathilde Bertrand, "Photographing the Miner's Strike at Lea Hall Colliery, 1984-1987: Interview with photographer Nigel Dickinson", Angles [Online], 1 | 2015, Online since 01 November 2015, connection on 07 June 2022. URL: http://journals.openedition.org/angles/2162 ; DOI: https://doi.org/10.4000/ angles. 2162

This text was automatically generated on 7 June 2022

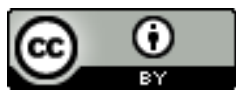

Angles est mise à disposition selon les termes de la Licence Creative Commons Attribution 4.0 International. 


\title{
Photographing the Miner's Strike at Lea Hall Colliery, 1984-1987: Interview with photographer Nigel Dickinson
}

\author{
Mathilde Bertrand
}

This media file cannot be displayed. Please refer to the online document http:// journals.openedition.org/angles/2162

\section{Transcript:}

Okay, well... This work I started at the beginning the strike. I went to Lee Hall colliery to a picket line by chance with a lot of friends. In fact, it was with the miner's support group from Birmingham miner's support group and we went to a lot of different picket lines. And when I went to the Lee Hall picket line, there was just something that happened there that made me want to go there again. It made me feel that I wanted to do something more important with that particular group of people.

2 In fact, the picture from the front of the book shows Huey, who is the black guy with the $\mathrm{V}$ sign like that [gestures] and the interesting thing about that picture, of course, is that on one level you know he's saying 'Victory!', but he's also saying 'Fuck you!' So that's the whole point. And Huey, who became a very good friend of mine, he was that type of person. He didn't care about getting arrested or doing anything that would antagonize the police, because it was always this relationship between the strikers on the police, where the police were trying to hold down the strikers, and the strikers trying to, you know, be empowered.

There was a very interesting little event that happened in the strike actually, a little bit later on, but I'll talk about it now... there was a Chief Inspector Nesbitt, and there was a song that was written by the cultural theatre group Banner Theatre. Banner Theatre was a musical group. Three Davids, I think they were, and they had one of their famous songs which was about Chief Inspector Nesbitt and it went something like: 'Chief 
Inspector Nesbitt, Chief Inspector Nesbitt, Chief Inspector Nesbitt, DI DI DEE, DI DI DEE DEE, DI DI DEE DEE. Now I'll tell you what the DI DI is once I've told you the story because, otherwise, that defeats the punchline.

4 It was wintertime. There was heavy snow. There was the legal number of strikers on the picket lines and they had built a snowman and Chief Inspector Nesbitt arrived with his Range Rover and he said to the strikers: 'Well, this snowman constitutes another person. You have to either get rid of the snowman or you have to get one man less on the picket.' And the people refused to do that. And Chief Inspector Nesbitt being that he was a bit of a bastard, like a lot of the police were, he reversed his Range Rover and ran over the Snowman. And the song went like this: 'It was DEE DEE DEE DEE and Chief Inspector Nesbitt ran over a concrete block and he totaled his car', totally, on this concrete block around which the Snowman was built... and wrecked his car. So that was one of the sort of highlights in the strike, and just one of those funny instances that happened.

5 Lee Hall was a minority bit. And that meant that there were something like 200 miners who were on strike, and there were something like 800 who were going to work. So Lee Hall was particular because of that. And there were a lot of minority bits in the Nottingham area and Staffordshire and that made it very difficult, and it also made Lee Hall very interesting because the solidarity that existed amongst the strikers - not just the strikers but also the women, the wives - was exceptionally strong.

6 The miners' wives to an extent held this strike together, because when it came towards the end of the strike, when some of the men started to feel the crunch, the lack of money, there were often women who were saying: 'You know we're out on strike with you; you don't go back.' And there was one woman who said to her husband quite famously: 'If you go back to work, I'll break your legs!' So there was this type of support that existed, this type of relationship that existed within the communities which made the solidarity of the strike so important.

7 For me, I started working at Lee Hall... and I suppose I went every single week from whatever time that I started going to this to the legal picket line... it wasn't at the very beginning, it was probably a month or two in, and probably I'd go up there a couple of times a week, sometimes I'd stay over, sometimes I'd stay in their houses, whatever... and I was very much a permanent member of the strike, if you like, as an outsider. And there were a lot of people going in and out of Lee Hall, and a lot of people from Lee Hall who were involved in the miners' support committee in Birmingham, which was a whole mixture of Trade Council, political parties, individuals and so forth.

8 And, to begin with, a lot of the solidarity that took place with the miners sort of came out from outside. And I think what happened during the strike was that the miners and the wives became more involved in everything that was supporting them, so that in fact it was them who were involved in the support groups. So it was actually... you know, you got rid of all the petty politics that happened to an extent, that began with different political parties, different left-wing groups who were there who wanted to push for their own ends. Classically there were certain groups at the beginning of the strike who didn't want to be collecting food for the miners or things like that. They wanted to be out on the picket lines and fighting for the miners.

9 And there was a classic cartoon in one of the papers of a striker on a picket line throwing a can of baked beans at a policeman, and it was ridiculed that this can of baked beans would hit the policemen and that would stop the strike. But, in fact, it was 
exactly that that was necessary, because eventually it became this war of attrition, and it became a very very long strike, a year-long strike, and it was the support and it was the solidarity of the people with the miners, and that was huge for that solidarity with them which enabled the miners to be on strike for so long.

In terms of my own involvement, I mean... I don't know... I mean it's like with most of the work that I do. I create a relationship and suddenly that work takes over. The work that I did with Lee Hall Colliery... I thought the work took place over a three or fouryear period. So it started in 1984 and the book probably was produced in 87, the exhibition in 86. So the book wasn't just about the strike itself, it was about the year after the strike, it was about all the solidarity, and it was also about the way in which the miners and the miners' wives learnt, and how they gave solidarity with other groups, so that it was actually about their development of people.

They were involved with me all the way through. I mean I became part of that group of people who were on strike. So that, in a way, relates to how I'd learnt to work, because when I was at college I was reading a lot, and I used to like reading Brecht, I used to like reading Walter Benjamin. I read this essay by Walter Benjamin, 'Author as producer,' and in that essay Walter Benjamin talks about the relationship with the means of production, and he says, I think, what is important is not the relationship... not the point of view that somebody has towards an activity, but what is his relationship within it, what is his relationship within the means of production, and to an extent that is something that operated for me... in terms of how I operate as a photographer or a filmmaker... is that I'm not just somebody who has a point of view. I'm somebody who works within, and I become part of that, and then to an extent I express a collective point of view about what's going on.

In the end of the book, when we eventually put the book to bed, if you like, or we put the exhibition to bed, first of all, we all got together and I brought some writers with me towards the end of the strike who were people from the same sort of political point of view, and people who had worked with Banner [Theatre] and had worked with Charlie Parker and had worked with this sort of history of the labour movement. They came from this history of working with labour movements and working in media and working in a way where they gave a voice to the people... who were filming or working in radio, or whatever happened to be.

13 So it wasn't just about, you know, being somebody like the BBC or a media and coming in and photographing and going away. It was giving people a voice and trying to represent those people's voices. And so that's what we did. We got together, we did lots of interviews with people, we got everybody together for a weekend, and for a whole weekend everybody talked about what had gone on during the strike. And we had pictures on the wall, we put texts that we'd had from previous weekends... Eventually you've got this exhibition, as it were pro forma exhibition, a rough exhibition: lots of pictures... And you can see that in the end of the book. There's a picture which shows all of us looking at these pictures, and people pointing at various pictures, and that's what happened.

14 And there were lots of disagreements about... there were lots of disagreements about, you know, which pictures should be in, and which texts should be in, and so forth... and we talked about it. And, to an extent, virtually everything that I wanted to put in, and the writers wanted to put in, was put in. There were things added, there were certain little things taken away, and, you know, it was a collective point of view that the 
problem was, of course... that there were some people who wouldn't like things that were said... So what happened was that when we had all these images on the wall, there were certain men who didn't like it to be said that they were chauvinist and macho. And the women had said these things, because it was the case. And we had arguments with the men to say, 'Well, look, you know, this is the point of view of the women.' You know that it was difficult for them, and they agreed that this had happened, but they thought that it detracted from the strengths of the work by having this type of conversations in the book, and we argued with them that actually this was a strength of the work because the work was about the reality of what happened. It wasn't trying to gloss over everything, it wasn't trying to gloss over what had actually happened, and what the difficulties were. So eventually all these things were left in.

One of the nice things after the work was produced was that the Lee Hall strikers and women ... I should say the Lee Hall miners and miners' wives, they took the exhibition around, and sometimes there were places where they would be able to put up the work, there were other times where right-wing councils or right-wing municipalities didn't want to put up the work. I was told of one event where they went down in a coach to this place with the exhibition, and because they were not allowed to put the exhibition up in the council house, or whatever it happened to be, they stood outside in the sort of plaza in front of the town hall and everybody held a panel of the exhibition and that's how they stood there for the whole afternoon. So this was marvellous. They felt very proud of this exhibition which was theirs, and, you know, this is what it was about: they were communicating through the work that we produced together something which they wanted to show to the rest of the world.

I took all the pictures, I mean, it wasn't as though they'd taken the pictures, but they had participated in the strike and the strike was about them, and 'Hanging On By Your Fingernails' [the title of the book] is, in a way, it's like a pamphlet about how to go on strike. It teaches people who've never been on strike, what could be the problems you'd face, and how do you get by. And then each double page, or each series of pages, deals with a different thing, and that's how it came together.

17 The way in which the project was financed... basically, to begin with, I financed everything myself. When it came to producing the exhibition, that was a time where I actually looked for financing, and I got finances twice from the West Midlands Art, which is part of the Arts Council of Great Britain, and they funded the production of the exhibition, and they also helped towards the production of the book which was then published by Spokesman Press. In terms of earning money, I didn't earn a great deal of money from it. I mean there wasn't enough money available in the pot to really make it work, and a lot of the miners were having a hard time. Some of them had been victimized, some of them had been sacked. What I agreed to do was to work for the minimum wage that a miner got, which was very small amount, and now when I look back on it, I think that was a terrific mark for solidarity, because I wouldn't work for those sort of wages ever again... but at that time, it seemed the best way to do it, and I knew that the miners and the strike committee and everybody else was reaching in their pockets to help it, so I did that myself as well. I mean, I worked all hours of the day to produce it, but I didn't mind. And a lot of friends came to help me to produce a book, to do the design and everything like that ... I was paid all the materials to produce the exhibition, etc. and I did it all myself. That was the time of typesetting and galley proofs and no computers or anything like that. So everything was typeset, all the 
pictures printed the exact size that they should be. They were stuck down onto a piece of paper and the typesetting was stuck down. So I did every single page and then we laminated it and just hoped that one of them wasn't wrecked on the panels, and none of them were, so we were okay.

So it was a solidarity... it was a solidarity action, it was a collective work. It was... we did it in the way that felt right and everybody was happy with it. I remember hunting for ages and ages and ages for a picture which would give this overall feeling of Lee Hall and the village, and the power station. The power station was this very important symbol of Lee Hall because Lee Hall quarry was right next to the power station. And then there was Rugeley itself, and there was this tree... and so that just was, I think for everybody, that was the image which presented in a way the death of that community, because unfortunately what happened was that Lee Hall was closed down, just like so many others.

If we look at this one here, the Lucky Strike... that was great. There was a lot of interesting people who supported the strike and she was... I can't remember her name, but she was like a sort of punk hippie person who had this huge knotted stump, as one of the miners' women called it, she said... I remember one of them said: 'Well, I wish my husband had a stump like this!' So these type of comments that came from miners... and it was this fantastic solidarity and also acceptance of other cultures, I mean. That was what was interesting because the miners were on the whole quite conservative, working-class people, but very much changed in the experience of the strike, and the people who came to help them and were in solidarity with them were people who were completely different to the type of people they would meet had they not been on strike. So this was one of the sort of marvelous things that happened during the strike... that it brought all these different types of people together.

Yes, this picture here... very important picture, probably one of the best pictures I did during the strike, who knows. I mean there was this propaganda from the government all the time. Lots of lies every single day. There were figures put up, released by the Coal Board and the government, shown on the BBC, with the numbers of people who apparently had gone back to work or had gone back to work... and so there was this war, really, this psychological war that was going on, and this picture epitomizes that, because you've got the striking miners' family who are sort of living in difficult circumstances, and the toys, and the things that they've got, and the coal that were given to them... all this comes from the solidarity that they received, so that picture is all about that.

21 There was this war of attrition that the $\mathrm{BBC}$ was fighting along with the government to make people go back to work. It was very hard and a lot of people couldn't take it any longer, and a lot of people went back to work, unfortunately. Not the majority, but some did, some couldn't deal with it and the people who went back to work felt guilty forever after, you know. And it was very very difficult. And, of course, there were even families where you had both working miner scabs and strikers in the same family, and that caused enormous splits. Well I think that the people who were proud were the strikers, you know. They were the people who fought. They didn't win, they lost the battle, they lost the war, but they came out with pride, yes.

There's a picture of me here, picture of the artist as a young lad, being kissed by one of the women. I think that was at Barnoldswick. I think it was a solidarity march for the 
garment workers in Lancashire, and it was just part of what happened out of the marvellous solidarity that the miners' wives and the miners felt, and they went and supported other strikes, and other struggles, in the same way they had been supported. may still be to do something more about the strike. I wanted to do Lee Hall revisited, I wanted to video people, I wanted to get people's point of view, I wanted to make an exhibition where we were photographing them before and now, and they were sort of interested in doing that, and it did rekindle some of the feelings that we had when we were working collectively, together. I had great difficulty getting funds for that, I had great difficulty getting interest from any major local gallery in the area of Birmingham, Wolverhampton, and Staffordshire, to actually put on a show and I had difficulty finding any support from the labour movement ... unfortunately I didn't carry it on. I mean, there's still the possibility of doing something, but I didn't do it. And what can you do? The $30^{\text {th }}$ anniversary has just gone, or is just in the middle of, so again ... it's a little bit like if I want to do it now, I have to do it by myself. There doesn't seem to be the support from anywhere to do it, and at the time when the strike was going on, it was really the time to do it. And I would never wish that I never did it because it was a fantastic thing to do, and it was part of solidarity and everything else, but now, to do a revisit, it's harder because people aren't together anymore. The miners' communities were full of solidarity and the miners' communities were full of solidarity not only in times of strike but in times of working in the mines, because the miners had to look after each other, so there was an extraordinary feeling of collectivity within the miners, and that's something that has been lost. And so for me to come back and do that again... it just didn't seem appropriate. We'll see maybe another time... I'm doing lots of other revisits to other projects.

\section{ABSTRACTS}

In the spring of 1984, a few months after the beginning of the Miner's Strike against pit closures, Nigel Dickinson joined the struggle of the miners and their families at Lea Hall colliery, a "minority pit" in Staffordshire, photographing all aspects of a dispute which went on for a year. His involvement with the community continued after the strike ended. Collectively, the Lea Hall Strike Centre used Dickinson's photographs for an exhibition shown around the country as well 
as a book entitled Hanging On By Your Fingernails (Spokesman Press, 1987). In this interview Nigel Dickinson talks about his personal involvement and working conditions, emphasizing the construction of a sense of collective action which the photographs contributed to sustain.

Au printemps 1984, quelques mois après le début de la grève des mineurs en Grande-Bretagne, Nigel Dickinson rejoint la lutte des grévistes et de leurs familles dans le village minier de Lea Hall dans le Staffordshire. Lea Hall Colliery est l'une des exploitations où les grévistes sont minoritaires. Le photographe documente tous les aspects de ce conflit qui s'est étiré sur un an. Son implication dans la communauté se poursuit jusqu'en 1987. Au long de cette période, les membres du Lea Hall Strike Centre, organisation qui gère le quotidien de la grève, travaillent en collaboration étroite avec Nigel Dickinson sur les photographies qu'il a réalisées, et produisent une exposition ainsi qu'un ouvrage intitulé Hanging On By Your Fingernails (Spokesman Press, 1987). Dans cet entretien, Nigel Dickinson évoque son engagement personnel dans la grève ainsi que ses conditions de travail. Il insiste sur le processus de construction d'un sens de l'action collective, processus dans lequel les photographies ont joué un rôle indéniable.

\section{INDEX}

Mots-clés: grève des mineurs, Royaume-Uni, Dickinson Nigel, photographie, représentation, action collective, participation, mémoire, syndicalisme, entretien

Keywords: UK, miner's strike, Dickinson Nigel, photography, representation, collective action, participation, memory, unions, interview

\section{AUTHOR}

\section{MATHILDE BERTRAND}

Mathilde Bertrand works as a teaching and research assistant (ATER) at the English Studies Department of the University of Paris Ouest Nanterre La Défense. In 2013 she defended her doctoral dissertation entitled "Between artistic institutionalisation and the invention of a politically radical independent photography: a study of practices, discourses and structures around photography in England from the late fifties to the late eighties". She worked under the joint supervision of Liliane Louvel (Université de Poitiers) and Cornelius Crowley (Université Paris Ouest). This research links the emergence of a politically radical independent photography in postwar England with contemporary debates on culture, politics and representation. Her research focuses on the interface between artistic and political practices in late 20th and early 21st century Britain, and on the history of British independent photography, with particular attention paid to practices such as "community photography". Contact: m4thilde.bertr4nd [at] gmail.com 